\title{
The Power of Two: Sharing Leadership for School Improvement in Indigenous Education
}

\author{
Louise Wilkinson
}

Sue McGinty

James Cook University

etropic 14.1 (2015):50-56. http://www.reefandleaf.com.au/etropic.html \& http://www.jcu.edu.au/etropic

\begin{abstract}
Australian schools are now under constant pressure to improve student results, particularly those of Indigenous students. To this end, successful school-community interrelationships are considered especially significant. This research focuses on a microcosm of such relationships, that is the one between Indigenous Education Workers (IEWs)/Community Education Counselors (CECs) and principals in the North Queensland educational region (NQR). It aims to examine and transform the professional relationship between these key people as they respond to and address implementation issues of 'Closing the Gap'. A qualitative participatory action research multi-site case study guided by a critical theorist framework will be conducted using a mixed methods approach. The research will be used to highlight best practice in educational leadership through planning and action. It has the potential to provide a new way of looking at educational leadership within the case study schools, NQR, and potentially to the wider system in the state of Queensland.
\end{abstract}

Keywords: Educational Leadership; Indigenous Education; school-community interrelationships

\section{Introduction}

Improving schools to reduce disadvantage and raise achievement' or 'closing the gap' are the much used current phrases within the field of school education in countries with diverse student populations. There is a shift from 'fixing the student' to improving the school. Achieving equity and excellence for disadvantaged students and making schools better equipped to do this have impacted on school operations both nationally and internationally (Council of Australian Governments Reform Council, 2012, p. 667; Organisation for Economic Co-Operation and Development, 2012a, 2012b).

An emerging body of research regarding Indigenous and non-Indigenous educational leadership practices in Indigenous communities, shows that where effective partnerships exist between parents, teachers and the community, the quality of schooling for all students improves, students enjoy more satisfying educational experiences, and communities are strengthened (Flückiger, Diamond, \& Jones, 2012; Frawley \& Fasoli, 2012; Kamara, 2009). Indigenous workers in schools usually come directly from the local community or are accepted by and identify with the local community (Northern Territory Department of Education (NTDE), 1999). If IEW/CECs form the bridge between their school and community, it could then be argued that there needs to be an effective working relationship between the IEW/CEC and their school's principal as this forms the foundation for strong school-community links. Currently, however, there is little documented research that focuses specifically on the Australian IEW/CEC and principal relationship and what occurs between them. 
This is an overlooked situation as both are key leader members of a school and both have a unique role to play in the improvement of Indigenous student learning outcomes and parent-schoolcommunity engagement. The proposed research seeks to contribute to this knowledge gap.

\section{Literature Review}

A literature review provided numerous compelling reasons from three contexts as to why this research is important.

At the forefront are the voices of many Aboriginal and Torres Strait Islander academics, educators, activists and community who continue to make calls to redress Australia's colonial past and the resultant inequalities for Aboriginal and Torres Strait Islander peoples. Many use a term called 'Unfinished Business'. The role of IEWs \& CECs in schools is in itself a product of early attempts to do this as they were and are considered vital in ensuring effective Indigenous participation in Australia's education system.

Central to "Unfinished Business" is reconciliation. An organisation called, 'Reconciliation Australia' was formed in the early 1990's as a result of the recommendations of the Royal Commission for Aboriginal Deaths in Custody. Mick Dodson (2009) defines the notion of reconciliation as material and interpersonal. He defines 'material' as meaning the “Australian Government's strategy of Closing the Gap on Indigenous disadvantage, that is their targets for closing the life expectancy gap, halving the infant mortality rate, equalising access to early childhood education, halving the year 12 attainment rate and halving the gap in employment outcomes...Equality is the base-line of any meaningful sense of material reconciliation' (2009, p. 2). Dodson then defines the 'interpersonal' something which resonates with the intent of this research, “...it is the 'reshaping [of] the inter-personal relationship between Indigenous and non-Indigenous Australians that is just as critical: but it is a less tangible, more amorphous endeavour” (2009, p. 2).

To this end, the nature of this inquiry draws from the social justice principles of 'parity of participation' (Fraser, 2007, p. 27), that of seeking elimination of inequalities for Aboriginal and Torres Strait Islander students in schooling. As such, it is based within the transformative research paradigm of Critical and Indigenous Theories, acknowledging the emancipatory work of Friere (1973) and explorations of 'the cultural interface' Nakata (2002). Interwoven with this to assist with the examination of the IEW/CEC - principal relationship is an interpretation of Relational Leadership (Bradbury \& Lichtenstein, 2000; Uhl-Bien, 2006).

The key questions driving this research are:

1. What is the current IEW/CEC - principal relationship?

2. How can this relationship be strengthened and what are the contextual features that influence this?

3. What are the outcomes of this strengthened relationship?

4. What are the implications for practice and policy in schools?

\section{Methodology}

The research is being conducted as a two-stage, multi-site case study using Participatory Action Research (PAR) (Kapoor \& Jordan, 2009; Kidd \& Kral, 2005; Koirala-Azad \& Fuentes, 2009) as the main methodological approach with at least two cycles of observing, reflecting, planning and acting 
over a two year period, commencing September 2013 (See Figure 1). Four pairs of volunteer IEWs/CECs and principals have been recruited to work with the paper's first author in actions deemed important to improve Indigenous student achievement. To reduce any onerous nature of the research, the actions of participants are authentically structured so they are not 'add on' but 'part of' usual school work (i.e. performance or strategic planning and program implementation).

The research questions will be answered through use of mixed methods and a variety of data sources such as: questionnaires, semi-structured interviews, critical incidents, focus groups, school/DETE documents, icons, artefacts, diary, field notes and enumeration data. Both quantitative and qualitative data results from of each cycle of action, will be analysed in three steps using an interactive model of data analysis (Denzin, Lincoln, \& Smith, 2008) to provide evidence and answers to the main and emerging micro research questions.

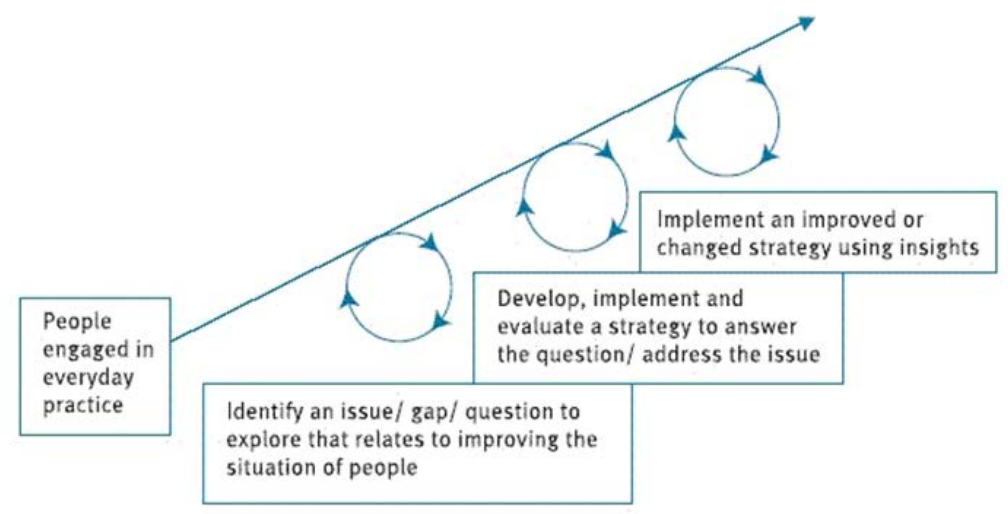

Figure 1: Participatory Action Research cycles

Once the first round of analysis on the data has been completed, the next step will be to search for meaning or patterns across all of the data items. This will be done through direct interpretation of the individual instance and aggregation of instances (Stake, 1995) including looking the data over again and again, reflecting and using what Denzin (1970, cited in Merriam, 1988, p. 69), Yin (1994) and Stake (2000) refer to as triangulation. Using this level of analysis the first author will look for assertions based on the findings that will be collated under headings derived from a response to the core issues of 'parity of participation' and 'relational trust' mentioned above. Finally, a synthesis of the analysis of the literature and the findings of the multi-site case studies will provide recommendations and a conclusion.

Integral to the methodological approach is the advice and support of four cultural mentors for the paper's first author. Two of whom work within DETE as CECs and two of whom are academics from James Cook University.

Results

To date, preliminary data has been gathered from two sources: Questionnaires distributed to almost all state school principals and IEWs/CECs across the North Qld region and structured interviews with four volunteer pairs of IEWs/CECs and principals. The interviews are under currently under analysis, however the questionnaire data has had its first round of analysis and some findings have emerged.

Four sections of both questionnaires gathered a snapshot of information about IEWs/CECs and principals in the North Queensland region: (1) their school context, (2) their perceptions on the nature of the work undertaken by IEWs/CECs, (3) what they do together and (4) willingness to 
participate in case study work with the first author. Both questionnaires had a similar format. An analysis of the questionnaires' findings provide some initial indications of the nature of the current IEW/CEC and principal relationship, including their general work and social contexts, initial relational co-work perceptions and willingness to be in the larger study. The results are presented in the section that follows.

\section{School Context}

The principal respondents' demographic profile mirrored the current principal demographic of the North Queensland Region for state schools; that is, there were many more relatively inexperienced than experienced principals (English, 2013). The IEW/CEC results confirmed past research findings that IEWs/CECs tend to have a greater stability of role and continuity at the same school than principals and are predominantly female (Buckskin \& Hignett, 1994; Northern Territory Department of Education, 1999). All principals were of non-Indigenous cultural background profile reflecting current Australian principal Indigenaeity trends. In 2012, there were only 78 principals who were Aboriginal and Torres Strait Islander across the whole of Australia in any jurisdiction (More Aboriginal and Torres Strait Islander Teachers Initiative [MATSITI], 2014). It would seem that in the North Queensland Region, not many IEWs/CECs and principals worked directly together, with supervision responsibility given to other classified school personnel. If and when they did meet, it was mostly 'as required'. Reasons for this could be attributed to school size; however, some of those who did work directly together were from large schools where the principal had not delegated this working relationship and they did meet frequently.

\section{Perception of the Work Undertaken by IEWs/CECs}

Overall the IEWs'/CECs' perception of their duties tended to a focus on areas such as student engagement, attendance and achievement. While the greatest single number of principal responses acknowledged the IEW/CEC role in working with students, generally principals saw the IEW/CEC role as most commonly one that provided advice, assistance and information about Aboriginal and Torres Strait Islander people to staff. As such, the above findings do resonate with those found in a survey of the handful of known empirical studies pertaining to the work of IEWs/CECs in Australia (Buckskin \& Hignett, 1994; Cahill \& Collard, 2003; Funnell, 2012; Gower et al., 2011; Grace \& Trudgett, 2012; MacGill, 2009; Pearce, 2011; Warren, Cooper, \& Baturo, 2004). Themes that emerged from these works included: (i) visibility and representation of IEWs/CECs within schools; (ii) amorphous roles performed by many IEWs/CECs; (iii) centricity to bridging the home-school divide; (iv) influence on building cultural responsiveness in other school staff; and, (v) influence on participation and achievement of Aboriginal and Torres Strait Islander students. The latter three were especially evident in the current questionnaires' findings.

The mismatch of perception by both groups around the role of the IEW/CEC likely reflects an under appreciation of the reach and influence of the IEW/CEC role not only by principals, but also by the very people who perform the duties - the IEWs/CECs themselves. Could this be an example of what happens when the social justice principle, 'participatory parity' (Fraser, 2007), is impeded? Is this mismatch of perception and low social esteem is a result of the historical non-achievement of equal opportunity dogging Aboriginal and Torres Strait Islander peoples over the past 200 years? These questions will be explored in the larger project's case studies. 


\section{Initial Relational Co-Work Perceptions}

Themes that emerged from responses by both groups in this section were related to: students, enacting school and system policies and school-home/community connections. These included school celebrations of the 'one-off' Indigenous calendar events like National Aboriginal and Islander Day of Commemoration (NAIDOC) or activities for students requiring parent involvement (i.e. disciplinary matters or attendance). Implementation of DETE policy like EATSIPS, however, was the only one perceived as a joint activity by the greatest number of respondents from both groups. It is known to the paper's first author that this co-work participation exposed IEWs/CECs and principals to the EATSIPS policy documents and regional training where they were introduced to the notion of a 'third cultural space' which directly connects to Nakata's Cultural Interface Theory: “The third cultural space recognises that Indigenous communities have distinct and deep cultural and world views - views that differ from those found in most Western education systems. When Western and Indigenous systems are acknowledged and valued equally, the overlapping or merging of views represents a new way of educating” (Department of Education and Training, 2011, p. 9)

This reinforces aspects of the paper's first author theoretical paradigm and will assist with participant development in the case studies.

\section{Further Participation Willingness}

The paper's first author provided a short oral presentation at the distribution of all questionnaires, citing the focus of the research was to examine the IEW/CEC relationship. The high number of positive responses greatly assisted in the process of identifying pairs of IEWs/CECs and principals for the case study schools.

\section{Conclusion}

The research completed to date captures a snapshot of the current IEW/CEC and principal relationship in state schools in the North Queensland region. The questionnaires reveal there is a significant reach of the IEW/CEC role across the school, yet at the same time, their role seems to be under estimated and underappreciated, not just by many principals but by IEWs/CECs themselves. There is also a perceived mismatch of agreement on co-work actions and where there is agreement, this tends to be in the area of school operations and routine. By further examining the IEW/CEC and principal relationship through the case studies, it is expected this work will make known, the 'space in between' the two roles, a place for overlap of leadership actions and '... where a mutual influence process" (Uhl-Bien, 2006, p. 667), may occur to maximise the power of two. This shift towards hybridity could give leverage to strengthen and transform the why, what and how of IEWs'/CECs' and principals' work together. It can offer practical implications to enhance their leadership impact on the learning outcomes of all students, especially those of Aboriginal and Torres Strait Islander students and their school-community interrelationships.

\section{Works Cited}

Bradbury, H., \& Lichtenstein, B. M. B. (2000). Relationality in Organizational Research: Exploring The Space Between. Organization Science, 11(5), 551-564. doi: 10.2307/2640345 
Buckskin, P., \& Hignett, B. S. (1994). ARA Kuwaritjakutu Project: Towards a new way: Stages 1 \& 2. A research project into the working conditions of Aboriginal and Torres Strait Islander Workers. Melbourne: Australian Education Union.

Cahill, R., \& Collard, G. (2003). "Deadly Ways to Learn" . . a Yarn about Some Learning We Did Together. Comparative Education, 39(2), 211-219. [JSTOR version]. doi: 10.2307/3099881

Council of Australian Governments Reform Council. (2012). Indigenous Reform. Retrieved 3 Dec 2012, from http://www.coagreformcouncil.gov.au/agenda/indigenous.cfm

Denzin, N., Lincoln, Y., \& Smith, L. (Eds.). (2008). Handbook of Critical and Indigenous Methodologies. Thousand Oaks, Calif: Sage.

Department of Education and Training. (2011). Embedding Aboriginal and Torres Strait Islander Perspectives in schools: A guide for school learning communities,. Brisbane, Australia: Author.

Dodson, M. (2009). How Well Do We Know Each Other? [Transcript of his speech to the ANU Reconciliation Lecture, Canberra on 5 June, 2009]. Retrieved 14 April, 2013, from http://ncis.anu.edu.au/_lib/doc/reconciliation_lecture/2009_mick_dodson_transcript.pdf

English, R. (2013). Powerpoint slide from Regional Director's presentation, North Queensland Region Principals' Forum 22-23 August 2013. internal regional website.

Flückiger, B., Diamond, P., \& Jones, W. (2012). Yarning space: Leading literacy learning through family-school partnerships. Australasian Journal of Early Childhood, 37(3), 53-59.

Fraser, N. (2007). Feminist Politics in the Age of Recognition: A Two-Dimensional Approach to Gender Justice. Studies in Social Justice, 1(1), 23-37.

Frawley, J., \& Fasoli, L. (2012). Working together: intercultural leadership capabilities for bothways education. School Leadership \& Management, 32(4), 309-320. doi:10.1080/13632434.2012.708328

Friere, P. (1973). Pedagogy of the oppressed. [Translated by Myra Bergman Ramos]. Middlesex, England: Penguin Education.

Funnell, R. (2012). Indigenous Education Workers: A Special Case of Educational Assistant. In R. Jorgensen, P. Sullivan \& P. Grootenboer (Eds.), Pedagogies to enhance learning for Indigenous students : Evidence-based practice (pp. 45-60). Singapore: Springer Science+Business Media. doi: 10.1007/978-981-4021-84-5

Gower, G., Partington, G., Byrne, M., Galloway, A., Weissofner, N., Ferguson, N., \& Kirov, E. (2011). Review Of The Aboriginal And Islander Education Officer Program: A report prepared for the Department of Education Western Australia. Retrieved from http://www.det.wa.edu.au/aboriginaleducation/detcms/cmsservice/download/asset/?asset_id=13256470

Grace, R., \& Trudgett, M. (2012). It's not rocket science: The perspectives of Indigenous early childhood workers on supporting the engagement of Indigenous families in early childhood settings. Australasian Journal of Early Childhood, 37(Jun 2012), 10 - 18.

Kamara, M. S. (2009). Indigenous female educational leaders in Northern Territory remote community schools : issues in negotiating school community partnerships. Australian Catholic University . Fitzroy Vic. Retrieved from http://dlibrary.acu.edu.au/digitaltheses/public/adt-acuvp279.02032011/

Kapoor, D., \& Jordan, S. (2009). Education, Participatory Action Research, and Social Change : International Perspectives. Retrieved from http://jcu.eblib.com.au/patron/FullRecord.aspx?p=555380

Kidd, S. A., \& Kral, M. J. (2005). Practicing participatory action research. Journal of Counseling Psychology, 52(2), 187-195.

Koirala-Azad, S., \& Fuentes, E. (2009). Introduction: Activist Scholarship - Possibilities and Constraints of Participatory Action Research. Social Justice, 36(4 (118)), 1-5. Retrieved from http://www.jstor.org/stable/29768557 
MacGill, B. (2009). Aboriginal Education Workers in South Australia: towards equality of recognition of Indigenous ethics of care practices. (Doctor of Philosophy), Flinders University. Retrieved from http://theses.flinders.edu.au/public/adt-SFU20090630.142151/

Merriam, S. (1988). Case Study Research in Education: A Qualitative Approach. San Francisco, CA: Jossey-Bass Inc.

More Aboriginal and Torres Strait Islander Teachers Initiative [MATSITI]. (2014). National Teacher workforce data. Retrieved 28 May 2014, from http://matsiti.edu.au/ntwd/

Nakata, M. (2002). Indigenous Knowledge and the Cultural Interface: underlying issues at the intersection of knowledge and information systems. IFLA Journal, 28(5-6), 281-291. doi: $10.1177 / 034003520202800513$

Northern Territory Department of Education. (1999). Learning lessons : an independent review of indigenous education in the Northern Territory. Darwin, NT: Government Printing Office of the Northern Territory.

Northern Territory Department of Education (NTDE). (1999). Leaming lessons: An independent review of Indigenous education in the Northern Territory. Darwin, NT: Author.

Organisation for Economic Co-Operation and Development. (2012a). Equity and Quality in Education: Supporting Disadvantaged Students and School: OECD Publishing.

Organisation for Economic Co-operation and Development. (2012b). Improving low performing disadvantaged schools (pp. 103-161 ). Paris, France: OECD Publishing. doi: 10.1787/9789264130852-5-en

Pearce, F. (2011). AEWs: Skilled uncles and aunties smoothing out the bumps on the road to learning. (Master of Education - Research thesis), University of Wollongong, Wollongong, New South Wales. Retrieved from http://ro.uow.edu.au/theses/3685

Stake, R. (1995). The Art of Case Study Research. Thousand Oaks, CA: Sage.

Stake, R. (2000). Case Studies. In N. D. Y. Lincoln (Ed.), Handbook of Qualitative Research (2nd ed., pp. 435-454). Thousand Oaks, CA: Sage.

Uhl-Bien, M. (2006). Relational Leadership Theory: Exploring the social processes of leadership and organizing. The Leadership Quarterly, 17(6), 654-676. doi:10.1016/j.leaqua.2006.10.007

Warren, E., Cooper, T. J., \& Baturo, A. R. (2004). Indigenous students and mathematics : teachers' perceptions of the role of teacher aides. [online]. Australian Journal of Indigenous Education, 33, 37-46.

Yin, R. (1994). Case Study Research: Design and Methods (2nd ed.). Thousand Oaks, CA: Sage. 